\title{
PENERAPAN PRINSIP GOOD GOVERNMENT GOVERNANCE DALAM PENGELOLAAN ALOKASI DANA DESA
}

\author{
Ana Bidayatul Maulida ${ }^{*}$, Arik Susbiyani ${ }^{1}$, Astrid Maharani ${ }^{1}$ \\ ${ }^{1}$ Universitas Muhammadiyah Jember, Jl. Karimata No. 49 Jember, Indonesia \\ "Korespondensi: maulidana2407@gmail.com
}

\begin{abstract}
Good government governance is good governance. This concept has been applied in the government sector to strengthen village autonomy. This study aims to analyze and describe the application of good government governance principles in managing village fund allocations in Ambulu village and to find out whether the management of village fund allocations in Ambulu village has met the principles of good government governance. This type of research was conducted with a qualitative method using a descriptive approach. The object of this research is the Ambulu Village Government located in Ambulu District, Jember Regency. The results of this study indicate that the Ambulu Village Government system has been running well and has met all indicators of good government governance (democracy, transparency, accountability, legal culture, as well as fairness and equality). The Ambulu Village Government has implemented the five principles of good government governance in real terms so that it can realize a government system with good governance. Good government governance that runs well can prosper the entire community equally.
\end{abstract}

Keywords: Good Government Governance, Village Fund Allocation, Democracy, Accountability, Transparency

\section{ABSTRAK}

Good government governance merupakan tata kelola pemerintahan yang baik. Konsep ini telah diterapkan dalam sektor pemerintahan untuk memperkuat otonomi desa. Penelitian ini bertujuan untuk menganalisis dan mendeskripsikan penerapan prinsip good government governance dalam pengelolaan alokasi dana desa di desa Ambulu dan untuk mengetahui apakah pengelolaan alokasi dana desa di desa Ambulu sudah memenuhi prinsip good government governance. Jenis Penelitian ini dilakukan dengan metode kualitatif menggunakan pendekatan deskriptif. Objek penelitian ini adalah Pemerintah Desa Ambulu yang terletak Kecamatan Ambulu, Kabupaten Jember. Hasil penelitian ini menunjukkan bahwa sistem Pemerintah Desa Ambulu sudah berjalan dengan baik dan sudah memenuhi semua indikator good government governance (demokrasi, transparansi, akuntabilitas, budaya hukum, serta kewajaran dan kesetaraan). Pemerintah Desa Ambulu sudah menerapkan kelima prinsip good government governance secara nyata sehingga dapat mewujudkan sistem pemerintahan dengan tata kelola yang baik. Good government governance yang berjalan dengan baik dapat mensejahterakan seluruh masyarakat secara merata.

Kata kunci: Good Government Governance, Alokasi Dana Desa, Demokrasi, Akuntabilitas, Transparansi 


\section{PENDAHULUAN}

Indonesia yang telah memasuki Era Globalisasi menyebabkan banyak persoalan yang dihadapi oleh pemerintahan pusat baik di dalam maupun di luar negeri. Oleh karena itu, pemerintah pusat tidak dapat mengelola pemerintah daerah secara optimal. Undang-undang Nomor 32 Tahun 2004 menjelaskan tentang kewenangan daerah otonomi untuk mengelolah dan memelihara kepentingan umum sesuai dengan peraturan perundang-undangan. Hal ini perlu dipahami istilah desentralisasi. Pemerintah pusat telah memberikan kewenangan yang lebih besar kepada kepala daerah untuk melaksanakan serangkaian proses, mekanisme, dan tahap perencanaan untuk memastikan keselarasan pembangunan yang harmonis (Thomas, 2013). Pemerintah daerah dalam proses pemberdayaan, peningkatan potensi dan sumber daya masyarakat, pemerintah daerah adalah Pemerintah Desa. Dalam pelaksanaannya, pemerintah tingkat desa memiliki kekuasaan dan kekuasaan tingkat desa meliputi penyelengaraan, perencanaan, pelaksanaan pembangunan desa, dan pemberdayaan masyarakat desa. Dalam pembangunan desa, pemerintah pusat telah menyerahkan seluruh kekuasaan kepada kepala Pemerintahan Desa. Untuk mendukung pembangunan desa, pemerintah pusat memberikan dukungan keuangan kepada setiap desa melalui pemerintah desa melalui alokasi dana desa (ADD).

Menurut Peraturan Bupati Jember Nomor 39 Tahun 2017, Pasal 4 dan Pasal 5 menjelaskan tentang penyaluran Alokasi Dana Desa. Pasal 4 meliputi penyaluran dana tingkat desa. Penyaluran alokasi dana desa dikelola berdasarkan prinsip transparansi; akuntabilitas; partisipasi serta keseimbangan dan kesetaraan serta dilaksanakan sesuai dengan urutan anggaran dan disiplin. Penyaluran alokasi dana desa mulai 1 Januari sampai dengan 31 Desember tahun berkenaan. Sedangkan pasal 5 mengenai penyaluran alokasi dana desa, yaitu dana yang dialokasikan oleh pemerintah kabupaten ke desa, dana tersebut merupakan bagian dari dana yang diperoleh pemerintah bupati dari perimbangan fiskal antara pemerintahan pusat dan pemerintah daerah setelah dikurangi dana alokasi khusus yaitu minimal 10\%. Dalam hal ini Pemerintah Desa dituntut untuk mengelola dan mengembangkan desa dengan baik agar terhindar dari penyelewengan. Oleh karena itu, dalam pengelolaan alokasi dana desa diharapkan sesuai dengan prinsip good government governance atau tata kelola pemerintahan yang baik, diantaranya akuntabilitas dan transparansi.

Good government governance merupakan tata pemerintahan yang baik yang diperkenalkan oleh pemerintah Indonesia. Pemerintahan Indonesia bertanggung jawab untuk menerapkan standar good government governance (tata kelola pemerintahan yang baik) yang telah diterapkan standar internasional (Sutedi, 2011). Pada penelitian ini melibatkan lima prinsip dari good government governance yaitu, demokrasi, transparansi, akuntabilitas, budaya hukum, kewajaran dan kesetaraan dalam memberikan solusi atau interprestasi pada pengelolaan alokasi dana desa. Penerapan prinsip good government governance memegang peranan penting dalam pengendalian penyelenggaraan pemerintah desa yang baik dan pencegahan korupsi. Pengelolaan dana desa untuk pembangunan dan pemberdayaan masyarakat desa diharapkan dapat meningkatkan kualitas masyarakat desa dan pemerintahan desa. Penerapan prinsip Alokasi Dana Desa dimulai dari tahap perencanaan, pelaksanaan, dan pertanggungjawaban.

Berdasarkan hasil observasi dan wawancara awal dengan perangkat desa ditemukan beberapa permasalahan, antara lain mengenai penggunaan alokasi dana desa di desa Ambulu lebih diperuntukan kepada belanja rutin pada bidang penyelenggaraan Pemerintah Desa dibandingkan untuk pembangunan sarana dan fasilitas pelayanan umum di desa setempat. Selain itu, rendahnya pengetahuan mengenai teknologi informasi sehingga tidak ada situs resmi dari pihak Pemerintah 
Desa Ambulu. Hal tersebut berdasarkan pendapat dari kepala desa Ambulu Kabupaten Jember yang mengatakan dalam penyusunan kegiatan perencanaan alokasi dana desa telah dilakukan musrenbangdes yang di hadiri oleh pengurus lembaga desa serta perwakilan masyarakat seperti kasun, RW dan sebagainya. (Mulyono, Kepala Desa Ambulu Kabupaten Jember, 2020).

\section{METODE PENELITIAN}

\section{Desain Penelitian}

Penelitian ini dilakukan dengan metode kualitatif menggunakan pendekatan deskriptif. Penelitian kualitatif adalah penelitian yang bertujuan mengamati fenomena alamiah, mengumpulkan informasi, dan menyajikan dalam hasil penelitian. Penelitian ini merupakan penelitian kualitatif yang dilakukan dalam bentuk studi kasus (Bungin, 2011). Fokus dari penelitian ini adalah penerapan prinsip good government governance dalam mengelola alokasi dana desa beserta kendala-kendala pada pemerintah desa, dengan prinsip good government governance sebagai berikut: prinsip demokrasi, transparansi, akuntabilitas, budaya hukum, kewajaran dan kesetaraan yang dilakukan oleh Pemerintah Desa.

\section{Lokasi dan objek penelitian}

Lokasi penelitian yang digunakan dalam penelitian adalah Desa Ambulu Kecamatan Ambulu Kabupaten Jember. Sedangkan objek dari penelitian ini adalah penerapan prinsip good government governance Desa Ambulu.

\section{Teknik Pengumpulan Data}

\section{Observasi}

Peneliti melakukan observasi atau pengamatan untuk mengamati dan mencatat gejala-gejala yang muncul pada objek penelitian dalam kondisi atau situasi alami atau aktual. Hal ini bertujuan untuk mendapatkan data yang lebih mendekati keadaan sebenarnya.

\section{Wawancara}

Peneliti melakukan wawancara terhadap pihak perangkat desa Ambulu dengan cara tanya jawab seputar penerapan prinsip good govermnent governance, pengelolaan alokasi dana desa dan kendala-kendala yang telah dihadapi Pemerintah Desa. Perangkat Desa diantaranya adalah kepala desa, sekertaris desa, bendahara desa.

\section{Dokumentasi}

Dokumentasi dalam penelitian ini untuk memperoleh data dan informasi dalam bentuk buku, jurnal, dokumen arsip, peraturan bupati, peraturan undangundang dan lain-lain.

\section{Teknik Analisis}

Analisi data dalam penelitian kualitatif dilakukan sebelum memasuki lapangan, selama di lapangan, dan setelah dilapangan. Sebelum menjelaskan berbagai teknik analisis data, terlebih dahulu dapat dijelaskan pengertian analisis data. Teknik analisis data mempunyai prinsip mengolah data dan menganalisis data yang terkumpul menjadi data yang sistematik, teratur, terstruktur, dan bermakna. Prinsip-prinsip good government governance perlu dipahami agar diperoleh tolak ukur kinerja pemerintah. Baik buruknya pemerintahan terkait dengan prinsipprinsip good governance dapat dievaluasi. Prinsip- prinsip good governance 
meliputi prinsip demokrasi, prinsip transparansi, prinsip akuntabilitas, prinsip budaya hukum, serta prinsip kewajaran dan kesetaraan.

Studi ini menggunakan naratif kualitatif. Dimana dalam studi ini data yang dikumpulkan pada bentuk suatu berita yg tertulis, gambar-gambar, berfikir dan melihat obyek atau kegiatan orang yg terdapat pada sekelilingnya menggunakan melakukan wawancara sebagai akibatnya keadaan yg sesungguhnya bisa tergambar menggunakan baik.

Penelitian Kualitatif menurut Saryono (2010), Penelitian kualitatif adalah penelitian yg dipakai buat menyelidiki, menemukan, menggambarkan, \& mengungkapkan kualitas atau keistimewaan menurut efek sosial yg nir bisa dijelaskan, diukur atau digambarkan melalui pendekatan kuantitatif.

\section{HASIL DAN PEMBAHASAN}

\section{Gambaran Umum Objek Penelitian}

Legenda mengenai nama Desa Ambulu sendiri memiliki kisah unik yang berasal dari banyaknya orang Madura sedang berkunjung dan menetap di daerah tersebut. Kebiasaan orang madura saat diperjalanan dan kelelahan mereka beristirahat di salah satu pohon besar di daerah tersebut dan orang-orang Madura tersebut sering mengatakan kata-kata "ambu gelu" dalam bahasa Madura yang artinya "berhenti dulu". Berdasarakan kata-kata yang sering terucap oleh orang madura dan masyarakat sekitar maka terbentuklah kata "Ambulu”, dengan adanya kebiasaan pengucapan kata tersebut daerah tersebut di beri nama "Desa Ambulu".

Desa Ambulu Kecamatan Ambulu terletak di wilayah bagian selatan Kabupaten Jember dengan jarak $12 \mathrm{~km}$ dari garis pantai Watu Ulo dan Pantai Papuma yang berbatasan langsung dengan Samudra Hindia. Desa Ambulu memliki luas wilayah 565 ha dan memiliki 3 Dusun diantaranya Dusun Sumberan, Dusun Krajan, dan Dusun Langon. Secara Geografis Desa Ambulu terletak di dataran rendah dan hamparan persawahan yang luas dan subur., adapun batas-batas wilayah Desa Ambulu Kecamatan Ambulu Kabupaten Jember sebagai berikut: Prinsip Demokrasi

Partisipasi masyarakat desa sangat penting dalam penyelenggaraan pemerintah desa, semua masyarakat desa memiliki hak suara dalam pengambilan keputusan baik secara langsung maupun tidak langsung. Untuk itu, masyarakat desa dituntut ikut berpartisipasi dalam proses pengelolaan alokasi dana desa mulai dari proses perencanaan sampai proses pengawasan.

Hasil analisis yang dilakukan oleh peneliti dalam pengelolaan alokasi dana desa dapat dilihat melalui tahapan perencanaan alokasi dana desa dengan melibatkan masyarakat. Sebelum dilakukannya tahapan perencanaan Pemerintah Desa mengadakan Musyawarah Perencanaan Pembangunan Desa atau Musrenbangdes melibatkan masyarakat setempat yang dihadiri kepala dusun, tokoh masyarakat, Ketua RT dan Ketua RW, seluruh Lembaga Kemasyarakatan Desa atau LKD, Karang Taruna Desa, LPMD, ibu PKK, dan BPD. Musrenbangdes diadakan di Balai desa Ambulu sebagai forum diskusi dan menyampaikan pendapat dari masyarakat dalam rencana kegiatan pembangunan desa. Hasil observasi dan wawancara di Desa Ambulu bahwa perencanaan alokasi dana desa menunjukkan adanya prinsip demokrasi sebagai indikator Good Government Governance. Seperti yang sudah dijelaskan mengenai kondisi lapangan menunjukkan bahwa masyarakat 
terlibat aktif dalam proses pengelolaan alokasi dana desa. Hal ini menunjukkan bahwa prinsip demokrasi sudah diwujudkan atau sudah diterapkan secara nyata oleh Pemerintah Desa Ambulu yang sesuai dengan Teri Demokrasi, sehingga Pemerintah Desa bisa mewujudkan good governance.

\section{Prinsip Transparansi}

Transparansi merupakan keterbukaan ataupun pengungkapan (disclosure) dan unsur penyediaan informasi yang memadai dan mudah diakses oleh pemangku kepentingan (Mardiasmo, 2009). Laporan alokasi dana desa terintegrasi dengan laporan APBDes. Publikasi Pengelolaan Dana Desa, Alokasi Dana Desa, Bagi Hasil Pajak dan Retribusi, minimal menggunakan banner dengan ukuran $3 \times 4$ meter (Peraturan Bupati Jember Nomor 14 Tahun 2018). Pemerintah desa dituntut untuk menyampaikan transparansi atau keterbukaan mengenai pengelolaan dana desa kepada masyarakat. Dalam pengelolaan alokasi dana desa menunjukkan bahwa Pemerintah Desa Ambulu telah menerapakan prinsip transparansi dengan baik.

Hasil analisis yang dilakukan oleh peneliti dalam pelaksanaan kegiatan alokasi dana desa ini diwajibkan pihak Pemerintah Desa untuk melakukan transparansi atau keterbukaan kepada masyarakat dan keterbukaan ini disampaikan dari Tim Pelaksana Kegiatan Desa. Wujud nyata dari dari Tim Pelaksana Kegiatan Desa dalam mendukung keterbukaan informasi program alokasi dana desa di Desa Ambulu adalah memasang banner informasi alokasi dana desa. Keterbukaan informasi ini merupakan upaya yang dilakukan Pemerintah Desa Ambulu untuk melaksanakan prinsip transparansi dalam pengelolaan alokasi dana desa. Berdasarkan tiga pernyataan yang sudah disampaikan serta hasil observasi secara langsung dengan objek menunjukkan bahwa Pemerintah Desa Ambulu sudah menerapkan prinsip transparansi yang merupakan indikator dari good government governance.

\section{Prinsip Akuntabilitas}

Teori Akuntabilitas ini merupakan konsep yang komplek, kewajiban mempertanggungjawabkan kepada pihak yang mempunyai wewenang untuk meminta pertanggungjawban (Wicaksono, 2015). Pertanggungjawaban penggunaan alokasi dana desa terintegrasi dengan pertanggungjawaban APBDes. Bukti pendukung pertanggungjawaban alokasi dana desa yang terealisasikan per tanggal 31 Desember dan paling lambat bulan Januarai Tahun berikutnya. Pemerintah Desa harus melaporkan semua kegiatan yang telah terealisasikan dalam penyelenggaraan pengelolaan alokasi dana desa dengan tepat waktu (Andini \& Ahmad, 2021). Bukti publikasi laporan pertanggungjawaban alokasi dana desa yang telah dituangkan dalam laporan pertanggungjawaban APBDes minimal menggunakan banner dengan ukuran $3 \times 4$ meter (Peraturan Bupati Jember Nomor 14 Tahun 2018). Hasil analisis yang dilakukan oleh peneliti dengan ini menyatakan Pemerintah desa Ambulu sudah menerapkan sistem akses mengenai laporan realisasi secara langsung ke Balai Desa dan belum menerapkan sistem online. Pemerintah Desa Ambulu ini sudah cukup baik dalam menerapkan prinsip Akuntabilitas secara nyata sebagai indikator good government governance salah satunya berupa laporan realisasi anggaran APBDes tahun 2020. 


\section{Prinsip Budaya Hukum}

Teori kepatuhan harus terealisasikan pada prinsip budaya hukum, dimana Pemerintah Desa dalam proses perencanaan hingga pengelolaan keuangan berdasarkan Undang-undang yang telah ditentukan. Dengan tertibnya Pemerintahan Desa dalam melaksanakan proses kegiatan yang dilakukan sesuai peraturan perundang-undangan maka kemungkinan pemerintah desa akan mewujudkan good governance (Rahman et al., 2018). Hasil analisis yang dilakukan oleh peneliti menunjukkan dengan mentaati peraturan yang ada Desa Ambulu dapat mewujudkan good governance dan menjalankan sistem pemerintahan mengenai pengelolaan alokasi dana desa di Desa Ambulu sudah menerapkan prinsip budaya hukum dengan baik dan sesuai dengan peraturan perundang-undangan yang telah ditetapkan.

\section{Prinsip Kewajaran dan Kesetaraan}

Teori Kewajaran dan kesetaraan mengandung unsur keadilan dan kejujuran, sehingga proses pelaksanaannya dapat diwujudkan perlakuan yang sama dari para pemangku kepentingan secara bertanggungjawab (Mardiasmo, 2009). Dengan mendorong partisipasi masyarakat didalam proses pelaksanaan pembangunan desa untuk mewujudkan masyarakat desa yang sejahtera dan mandiri. Sejahtera dalam pelaksanaan pembangun bagi masyarakat ini harus dilakukan secara adil, merata atau menyeluruh (Peraturan Bupati Jember Nomor 14 Tahun 2018). Salah satu dari kewajaran dan kesetaraan di Pemerintah Desa Ambulu telah yaitu dengan kegiatan Musdus dan Musrenbangdes. Hal ini seperti yang sudah disampaikan oleh Sekertaris Desa semua pihak yang hadir dalam acara Musrenbangdes ini tidak pandang bulu yang artinya semua kalangan masyarakat ikut andil dalam proses perencanaan pengelolaan alokasi dana desa.

Hasil analisis yang dilakukan oleh peneliti dapat menunjukkan bahwasanya pihak Pemerintah Desa melibatkan semua kalangan masyarakat untuk ikut berpartisipasi dalam proses Musdus dan Musrenbangdes. Semua kegiatan yang dilakukan Pemerintah Desa Ambulu ini dalam menjalankan kegiatan pengelolaan alokasi dana desa berdasarkan aspirasi masyarakat setempat yang telah disetujui bersama, dan diharapkan dapat membangun desa secara merata. Hal ini bertujuan terwujudnya harapan masyarakat mengenai pembangunan desa yang baik dan dapat menyeluruh di Desa Ambulu. Berdasarkan pernyataan yang telah disampaikan bahwa Pemerintah Desa Ambulu telah menerapkan prinsip kewajaran dan kesetaraan dengan baik, sehinggah dalam proses pelaksanaan alokasi dana desa ini dapat dilakukan secara merata di Desa Ambulu.

\section{SIMPULAN}

Hasil penelitian yang telah dilakukan secara umum mengenai pengelolaan alokasi dana desa di Desa Ambulu ini sudah dapat dikatakan berjalan dengan baik dan sudah memenuhi semua indikator good government governance (demokrasi, transparansi, akuntabilitas, budaya hukum, serta kewajaran dan kesetaraan). Pemerintah Desa Ambulu sudah menerapkan kelima prinsip good government governance secara nyata sehingga dapat mewujudkan sistem pemerintahan dengan tata kelola yang baik. Good government governance yang berjalan dengan baik dapat mensejahterakan seluruh masyarakat secara merata. 
Penelitian ini dilakukan di desa Ambulu dengan subjek yang akan diteliti yaitu pemerintah desa seperti kepala desa, bendahara desa, sekertaris desa. Penerapan prinsip good government governance yang akan diteliti berfokus penelitian pada penerapan prinsip demokrasi, transparansi, akuntabilitas, budaya hukum, kewajaran kesetaraan yang dilakukan oleh pemerintah desa dalam mengelola dana desa. Hal ini dilakukan agar pokok pembahasan tidak semakin luas.

Untuk memenuhi prinsip Demokrasi, pemerintah Desa Ambulu ini harus mensosialisasikan kepada masyarakat sekitar supaya menumbuhkan kesadaran masyarakat terhadap pentingnya keterlibatan masyarakat dalam pengelolaan alokasi dana desa dalam proses pembangunan desa terutama dalam proses pengawasan. Berdasarkan hasil pengamatan dilapangan mengenai rendahnya penggunaan teknologi informasi, pemerintah desa harus mengadakan pelatihan kepada perangkat desa agar mempelajari dan dapat membuat situs resmi Desa sehingga masyarakat desa bisa mengakses informasi desa baik mengenai informasi kegiatan yang akan dilakukan maupun mengenai laporan realisasai APBDes. Pemasangan banner di setiap dusun supaya masyarakat sekitar mengetahui program kegiatan apa saja yang sudah dilaksanakan oleh pemerintah Desa Ambulu. Dan perlu dibangun sistem aplikasi kompoter untuk mempercepat dan mengurangi kesalahan proses pembuatan dokumen SPJ dan laporan pelaksanaan alokasi dana desa

\section{DAFTAR RUJUKAN}

Andini, D. P., \& Ahmad, A. (2021). The Accountability of the Village Fund Allocation Management at Jenggawah Village, Jember Regency. The First International Conference on Social Science, Humanity, and Public Health (ICOSHIP 2020), 7478.

BAPPENAS, B. P. P. N. (2004). Undang-Undang No 32 Tahun 2004 Tentang Pemerintah Daerah. Dpr, 249.

Bungin, B. (2011). Penelitian Kualitatif: Komunikasi, Ekonomi, Kebijakan Publik, Dan Ilmu Sosial Lainnya. In Kencana.

Mardiasmo. (2009). Akuntansi Sektor Publik (IV). ANDI OFFSET.

Peraturan Bupati Jember Nomor 14 Tahun 2018. (2018). Kabupaten Jember.

Peraturan Bupati Jember Nomor 39 Tahun 2017 Tentang Pedoman Pengelolaan Alokasi Dana Desa. (2017).

Rahman, M. A., Suwandi, M., \& Hamid, A. (2018). Transparansi dan Akuntabilitas Pengelolaan Keuangan Alokasi Dana Desa (ADD) dalam Pencapaian Good Governance (Studi Empiris di Kecamatan Bontomarannu Kabupaten Gowa). Journal Accounting, 53(9), 1689-1699.

Saryono. (2010). Metode Penelitian Kualitatif. Alfabeta.

Sutedi, A. (2011). Good Corporate Governance (Pertama). Sinar Grafika.

Thomas. (2013). Pengelolaan Alokasi Dana Desa dalam Upaya Meningkatkan Pembangunan Di Desa Sebawang Kecamatan Sesayap Kabupaten Tana Tidung. Ejurnal Pemerintahan Integratif, 51-64.

Wicaksono, K. W. (2015). Akuntabilitas Organisasi Sektor Publik. JKAP (Jurnal Kebijakan Dan Administrasi Publik). https://doi.org/10.22146/jkap.7523 